\title{
Geopolitical and economic rivalry of capitalist powers for influences in Uzbekistan
}

Keywords: Uzbekistan, capitalism, isolationism, imperialism, geopolitics

\begin{abstract}
The present paper aims to present the rivalry of global and regional capitalist powers for political, strategic, diplomatic, and economic influences in the contemporary Republic of Uzbekistan. The modern history and the contemporary political situation of the Uzbek state are the most important points of issue. After years of international isolation and etatist social and economic policy, under the new political leadership Uzbekistan implements economic transformation in the spirit of neo-liberal capitalism and it opens itself towards different forms of international cooperation and foreign investments. As a result, a Central Asian country which was isolated until recently gradually becomes an object of rivalry for economic and geopolitical influences. So far Uzbekistan has not become a satellite state or a quasi-colony of any of the powers. The multi-vector policy pursued by the political environment of Shavkat Mirziyoyev seems so far to successfully prevent the country being dominated by any outside center. The present article brings up the subject of relations of Uzbekistan with four great powers: the United States of America, the Russian Federation, the People's Republic of China, and the Republic of Turkey.
\end{abstract}

* ORCID ID: https://orcid.org/0000-0002-9255-7417; $\mathrm{PhD}$ in humanities in the field of political science. His interests include international relations within the post-Soviet area and the Far East, ethnopolitics, unconventional political thought and religions of the East. Assistant professor at the Institute of Russian and Eastern Studies of the University of Gdańsk. Email: przemyslaw.sieradzan@ug.edu.pl 


\section{Introduction}

The purpose of the present study is a multi-aspect presentation of competition between the world and regional powers for political, strategic, diplomatic and economic influence in the contemporary Republic of Uzbekistan. The subject of the present paper refers first of all to the newest history and the contemporary political situation of the Uzbek state. The analyses contained in the article are kept in the spirit of an interdisciplinary approach characteristic of political sciences and expressed in a selective reference to the achievements of different scientific disciplines and sub-disciplines, with special regard to history, geography, science on civilization, economy and anthropology.

It is difficult to include the Republic of Uzbekistan ${ }^{1}$ among the states arousing considerable interest among scientists, journalists, analysts or other observers of the international situation. Although its territory is found in the geographical center of the Euro-Asiatic continent, paradoxically it is in the periphery of the world capitalist order. In the public discourse, Uzbekistan is frequently treated not as a separate entity of its own specific character but as a part of a larger whole - unreflectively mentioned "after a coma" next to other post-Soviet states of the region (Kazakhstan, Turkmenistan, Kyrgyzstan, Tajikistan), in the American (and not only American) journalism called slightly contemptuously "the Stans". This kind of approach seems to have been inherited from the colonial contempt for non-European civilizations and the patronizing attitude, which Edward Said called "orientalism"2.

The territory of today's Uzbekistan, like all Central Asia, has not always played a marginal role in the world's history. The Great Silk Road went though the lands of historical Western Turkestan. It was a trade road which connected China with the Near East and Europe between the $3^{\text {rd }}$ century B.C. and the $17^{\text {th }}$ century A.D. In the past strong and wealthy countries as well as cultural, political and economic centers were found in the area of today's Uzbek state, for example Scythia, Bactria, Transoxiana, Samarkand, Bukhara and Khiva, which frequently surpassed Europe in their technological development and material wealth. It is here where the heart of the huge Empire of the Timurid dynasty was found. It was an enormous power of the Late Middle Ages and the early Modern Era. That state gradually sank into crisis until it finally underwent

\footnotetext{
1 On the geography, history and demography of Uzbekistan, see: T. Bodio (ed.), Uzbekistan. Historia-społeczeństwo-polityka, Warszawa 2001.

2 Cf. E. Said, Orientalizm, Poznań 2005.
} 
disintegration. In the $19^{\text {th }}$ Russia and Great Britain fought for supremacy in this region which was then called Turkestan (at that time comprising three independent states, namely the Emirate of Bukhara, the Khanate of Kokand and the Khanate of Khiva) ${ }^{3}$. In 1868 Russia annexed Samarkand, the rest of the Emirate of Bukhara remained a satellite state of Russia until the revolution of 1917, while Kokand was finally incorporated into the Turkestanian governorate in $1876^{4}$. A small but hardly accessible Khanate of Khiva accepted the status of a vassal state in 1873. It was then that the whole territory of later Uzbekistan was incorporated into Russia or found itself under it control. Great Britain did not have the forces to counteract the Russian expansion in Turkestan. An attempt to divide the zones of influences between the empires took place in $1873^{5}$. This meant the actual agreement of the British crown for Russia to take over control over the territory of today's Uzbekistan, which was sealed with the British-Russian alliance pact from 31 August 1907. Since then the power of Saint-Petersburg over the territory of Uzbekistan was unlimited. The earliest beginnings of the capitalistic mode of production in the Turkestanian province date back to the second decade of the $20^{\text {th }} \mathrm{c}$, when the Russian capital made certain investments into the development of textile industry.

The next chapter in the history of Uzbekistan began just after the Russian revolution, when the Turkestan Autonomous Soviet Socialist Republic (within the composition of Soviet Russia) came into being in April 1918. Bukhara and Khiva kept their independence as small feudal states till 1920, when they were conquered by the Red Army ${ }^{6}$. They were replaced by the Bukharan and the Khorezm People's Soviet Republics, which existed as independent entities for four years. Advocates of the feudal order brought a counter-revolutionary Basmachi movement into life but it was ultimately suppressed in 1924. In October of that same year the Uzbek Soviet Socialist Republic was established (initially, with the capital in Samarkand, and since 1930 in Tashkent), which also com-

3 The fight for Turkiestan was a part of rivalry for Central Asia, which became known in history as "The Great Game”. See: M. Leontev, Bol'šâ igra: britanskaâ imperiâ protiv Rossii i SSSR, Moskva 2008; P. Hopkirk, Wielka Gra. Sekretna wojna o Azje Środkowa, Poznań 2011.

4 Ibidem, pp. 419-433.

5 Cf. M. Yetisggin, The Anglo-Russian Rivalry, Russia's Annexation of Merv and the Consequences of the Annexation on Turkmens, «Bilig. Journal of Social Sciences of the Turkic World» Winter 2007, No 40, pp. 141-167.

6 A. Khalid, Making Uzbekistan. Nation, Empire and the Revolution in the Early USSR, Ithaca and London 2015, pp. 156-217. 
prised Bukhara and (partly) Khwarezm, earlier incorporated into the Russian Soviet Socialist Republic ${ }^{7}$.

Since then Uzbekistan functioned as an integral part of the Soviet state. Within the specialization of particular region in the economic structure of the USSR, a very intensive cultivation of cotton was mainly developed in Uzbekistan (the peak of this specialization fell on the period when Sharaf Rashidovich Rashidov ruled in the years 1959-1983) ${ }^{8}$. A negative effect of such a policy included ecological degradation caused by an intensive application of artificial fertilizers and a huge consumption of water from the Syr Darya and the Amu Darya rivers (the consequence was contamination of the soils and ground waters and a partial drying up of the Aral Sea) ${ }^{9}$.

The policy of perestroika pursued by Mikhail Gorbachev brought an economic crisis to Uzbekistan following from a gradual restriction of the subsidies whose beneficiary was the republic. In 1989 an opposition nationalistic organization Birlik was established there with the aim of gaining independence but it received only a limited support ${ }^{10}$. In March 1990 the position of the president of the Uzbek Soviet Socialist Republic was created and it was taken by the $1^{\text {st }}$ Secretary of the Communist Party of Uzbekistan Islam Karimov. He was loyal to the central authorities in Moscow until the events of the August coup d'état in 1991. Although initially the authorities of the Uzbek SSR were rather inclined to support Gennady Ivanovich Yanayev's conservative party, after the coup they changed sides and on 31 January 1991 The Supreme Soviet of the Uzbek SSR announced independence of the country with Islam Karimov as its head.

Like in the $19^{\text {th }}$ century, in today's Central Asia there is a competition going on between imperialist powers for domination and influences and - as a consequence - for raw materials, markets and transport corridors. Uzbekistan, the largest state of the region considering the population, arouses special interest among the leaders of the world's powers. The state's political elites try to defend Uzbekistan's subjectivity and at the same time their own privileged position in different ways, whether

7 Ibidem, pp. 257-289.

8 First Secretary of the Communist Party of Uzbekistan Sharov Rashidov managed to build a very strong position to which he owed a considerable degree of independence from the central authorities. After his death in 1983, an anti-corruptive purge took place and Uzbekistan's autonomy was abolished.

9 Cf. L. Melvin, Uzbekistan: Transition to Authoritarianism, Amsterdam 2000, p. 75.

10 Cf. V. Babak, D. Vaisman, A. Wasserman, Political Organization in Central Asia and Azerbaijan, London-Portland 2004, p. 352. 
following the course of isolationism or realizing the multi-vector strategy based on balancing the influence of different powers. The economic potential and the place in the world division of work seem, however, to doom Uzbekistan to the role of a peripheral country, which is the object of competition for domination between the powers.

The development of the transcontinental program of infrastructural investments initiated and financed by the People's Republic of China and called "One Belt, One Road" or (mainly in journalism) "The New Silk Road", where the territory of Uzbekistan plays the key role, can affect a significant increase of the state's importance in the structure of production and distribution of goods which is characteristic of the contemporary world capitalistic system.

\section{Independent Uzbekistan between isolationism and participation in the global capitalist system}

For the first two and a half decades the main architect of the policy of independent Uzbekistan was Islam Karimov, in the years 1989-1991 the First Secretary of the Central Committee of the local communist party, and since March 1990 until his death on 2 September 2016 - the head of state. After the fall of the Soviet Union he faced numerous and hard challenges, the most important one being a deep economic collapse resulting from the weakening of the existing trade relations and broken chains of supplies, which was devastating for the republic, which largely based its production on the monoculture of cotton cultivation. The Uzbek ruling authorities decided, however, that the greatest threat for the country was not economic depression but destabilization of power ${ }^{11}$. A conservative course of policy was adopted, the result of which was many-years' petrifaction of the political system with a simultaneous preservation of relative independence from outside factors (which is reflected, for example, in a very low level of foreign debt ${ }^{12}$ ). A characteristic feature of the Uzbek model of statehood was the omnipotence of the National Security Service, which had unlimited control over the social and economic life of the country.

11 Cf. I. Karimow, Uzbekistan na progu XXI wieku, Warszawa 2001, p. 5.

12 Cf. K. Ruziev, Uzbekistan's Development Experiment: An Assessment of Karimov's Peculiar Economic Legacy, «Europe-Asia Studies» April 2020, https://www.researchgate.net/publication/341727474_Uzbekistan's_Development_Experiment_An_Assessment_of_Karimov's_ Peculiar_Economic_Legacy (14.11.2020). 
Islam Karimov built the model of the state based on the capitalist economy with the domination of state monopolies, largely based on the procedures and methods from the final period of the existence of the Soviet state. Unwillingness to conduct any reforms resulted in part from the belief that an introduction of thorough changes could bring about chaos. Uzbekistan combined the economy largely resembling the Soviet model with the nationalistic political ideology assuming de-Russification and Uzbekization of the social awareness, condemnation of the Soviet past and a struggle against the communist symbols. Paradoxically, a conservative and etatist policy was pursued, while the official propaganda glorified market economy and capitalism in the neoliberal version ${ }^{13}$.

In its foreign policy Uzbekistan governed by Islam Karimov realized an isolationist course, assuming limited contacts with any outside forces, including the countries of the region perceived as potentially hostile and treated with considerable distrust. A similarly negative attitude was presented by the authorities in Tashkent towards the Uzbek diaspora in post-Soviet states whose representatives were commonly accused of disloyalty. Islam Karimov's dislike for the neighbouring countries caused territorial conflicts, a lack of border delimitation, closed border crossings and closed down airline connections. Until 2016 the political elites of Tashkent, with certain important exceptions ${ }^{14}$ - limited international contacts. Even though Uzbekistan did not approach the autarkic model to the extent that Turkmenistan did, the policy of this country certainly fit the isolationist current.

The model of capitalism built in Uzbekistan in the times of Islam Karimov was principally different from the Russian, Kazakh or Ukrainian models. The stratum of oligarchs and big capitalists controlling considerable industrial and financial assets enabling them to affect the authorities was not established there. In Uzbekistan the capital was controlled by state officials (connected with the government administration, the judiciary, the armed forces and special services), who became the wealthiest persons in the country. Any attempts to concentrate too large amounts of capital by the entities independent from the authorities were thwarted with the help of proper services subordinated to the state power min-

13 Cf. I. Karimow, Uzbekistan na progu XXI wieku, Warszawa 2001, pp. 121-122.

14 The most important exceptions included contacts with the American authorities in the years 2001-2005 and the meetings with representatives of the Russian elites. 
istries. Thus the state dignitaries and their extended families took over full control of the Uzbek economy ${ }^{15}$.

Essential changes in social, economic and foreign policies of Uzbekistan took place after the death of Islam Karimov on 2 September 2016. It brought fundamental changes in the Uzbek statehood and caused a short constitutional crisis ${ }^{16}$. Although the new president Shavkat Miromonovich Mirziyoyev, as a many years' prime minister (in the period 2003-2016) belonged to a strict and narrow circle of Islam Karimov's co-workers and throughout that time did not gain the reputation of an advocate of reforms, showing no inclination to any insubordination, almost immediately after taking over the power decided to initiate a program of the state's transformation in the spirit of neoliberal capitalism in a number of fields of social, political and economic life.

Shavkat Mirziyoyev, till then considered to be a technocrat loyal to Karimov, quickly gained personal authority necessary to pursue a policy of reforms. His presidency was connected with initiated transformation of the state, monopolist bureaucratic capitalism into neoliberal capitalism with a growing role of private ownership and foreign capital. Although the authoritarian foundations of the political model of state were not shaken, a certain liberalization of the political life took place in Uzbekistan. The new president declared war to the National Security Service, whose chiefs were imprisoned or downgraded. Purges also took place in the army, in fiscal and financial institutions as well as in courts and prosecutor's offices. What is more, a considerable number of political prisoners were freed, the range of religious freedoms, freedom of speech, freedom of the press was extended and censorship was limited ${ }^{17}$.

In the field of economy, Shavkat Mirziyoyev adheres to the doctrine of neoliberalism. One of the major economic reforms which he implemented was to "liberate" the som - the Uzbek currency - through repealing the ban on individual transactions on the exchange market. The inevitable consequence of this policy was devaluation of the som, which lost over a half of its earlier value, the loss of the purchasing power, a decrease of the worth of the citizens' savings and impoverishment

15 R. Sattarov, Alisher Usmanov: Uzbekistan's Oligarch of Choice, https://carnegie.ru/commentary/74756 (5.11.2020).

16 Cf. M. Marszewski, Odwil $\dot{z}$ w Uzbekistanie. Reformy prezydenta Mirzijojewa, «Komentarze OSW» 2018, No. 278.

17 B. Zakirov, Can Mirziyoyev's Reforms Bring About a Real Free Market Economy in Uzbekistan?, https://thediplomat.com/2020/05/can-mirziyoyevs-reforms-bring-about-a-real-free-marketeconomy-in-uzbekistan/ (3.11.2020); T. Bodio, Uzbekistan - państwo $w$ totalnej przebudowie, «Nowa Polityka Wschodnia»2020, No 2. 
of the consumers. Neoliberal economic reforms included agriculture, in particular the cultivation of cotton and wheat (the system largely based on the hegemony of state ownership started to be replaced by the mechanisms of public and private cooperation) ${ }^{18}$.

Shavkat Mirziyoyev did not conceal his inspirations with monetarist economy and he spoke for the solutions referring to neoliberal capitalism. He started a program of reforms including restructuring of nonprofitable enterprises (which was connected with collective dismissals of employees) and a program of support for private companies, which was reflected, for example, in restricting the state's role in economy, departing from planning and increasing the role of market mechanisms ${ }^{19}$. The new policy is accompanied by a fast growth of social inequalities, which was feared by Islam Karimov (he thought that a too high level of inequalities could lead to social destabilization ${ }^{20}$ ). The existing policy of systematic repressions and purges in state authorities addressed against the Uzbek groups of owners (for example, regular show trials of millionaires, property confiscation by the state treasury) was replaced by the policy of state privileges for the domestic bourgeoisie. Thanks to the economic reforms carried out in the spirit of neoliberal capitalism and attempts to attract foreign capital (for instance, by gaining the favour of the Russian oligarchic capitalists, whom Karimov avoided, perceiving them as a potential threat to his power) as well as a simultaneous authoritarian style of the governance, Shavkat Mirziyoyev won the press name of the "Uzbek Deng Xiaoping"21. Mirziyoyev's activities were, for example, aimed at making the Uzbek capitalists who had been forced to emigrate during Karimov's presidency and now living abroad (e.g. in Russia, Ukraine, Kazakhstan, the United Arab Emirates and Malaysia) invest in Uzbekistan or even return to the country. The policy of neoliberal reforms described here did not encounter resistance from the workers' movement, which is very weak in Uzbekistan (the only trade union center is the Federation of Trade Unions of Uzbekistan).

As a consequence of a departure from the earlier doctrine of isolationism, the new political elites of Uzbekistan took the course towards

18 Vosem' glavnyh reform Šavkata Mirzieeva, https://glavportal.com/materials/vosem-glavnyhreform-shavkata-mirziyoeva (5.11.2020).

19 T. Bodio, Uzbekistan - państwo $w$ totalnej przebudowie...

20 R. Sattarov, Alisher Usmanov: Uzbekistan's Oligarch of Choice, https://carnegie.ru/commentary/74756 (5.11.2020).

21 Uzbekskij Den Siaopin: novaâ vnešnââ politika Šavkata Mirzieeva, https://russiancouncil.ru/ blogs/sofia-paderina/33998/ (5.11.2020). 
the state's integration with the global capitalistic system. This policy meant agreement for an incomparably greater role of the foreign capital in the state's economy. Huge powers began competition for influence in strategically located central Asian country. So far the leaders of Uzbekistan have managed to balance between the zones of influences of different powers, owing to which none of them has been able to win the hegemonic position.

\section{Uzbekistan in the foreign policy of the United States}

The United States has been the most powerful capitalist state of the world, at least since the end of World War II. Since the collapse of the Soviet Union in 1991 it has occupied the hegemonic position in the structure of the world order but this position is undergoing erosion together with successive strengthening of regional powers which question the logic of a "unipolar order". At the moment the present study is being prepared the United States, although getting relatively weaker and weaker for years, remains a capitalistic state which is stronger than its rivals both in the economic and military dimensions. There exists a consensus among representatives of the political elites of the United States (connected with both the Republican Part and the Democratic Party) on the necessity of defending the hegemonic position of the state (usually euphemistically called the "American global leadership")22 against the real and potential competitors in the whole world. The economic and military power enables the Washington politicians to treat the whole world as their own zone of influences. As a result, Central Asia - geographically far away - is also within the range of interests of those who make key decisions on the foreign policy of the Unites States.

Although due to its strategic location Uzbekistan has been and still is quite a significant country from the point of view of the American political elites, the political influences of Washington in this Central Asian state are not considerable now and - as it seems - they show a declining tendency. This results from the fact that the American imperialistic center is getting relatively weaker as well as from its involvement in many other points of the globe, which makes competition with Beijing and

22 Cf. e.g. A. De Hoop-Scheffer, R. Kinane, M. Quencez, X. Wickett, The Future of US Global Leadership. Implications for Europe, Canada and Transatlantic cooperation, German Marshall Fund of the United State 2016. 
Moscow more difficult. However, two decades ago the situation looked completely different.

On 25 December 1991 the United States recognized Uzbekistan as an independent country and in March 1992 the embassy in Tashkent was opened. The government in Washington tried to win the favour of Islam Karimov's political environment by assigning certain (rather small) funds to support the cross border services, programs of regional development, infrastructure development, regional development and non-governmental organizations as well as the spread of the English language teaching in Uzbekistan. The American political elites perceived Uzbekistan as a state of certain importance from the point of view of their interests in the region and hence the largest amounts of money were designed to combat the phenomena seen as the factors destabilizing the regional architecture of security such as drug production and transactions, human trafficking, terrorism and extremism motivated by religion ${ }^{23}$. During Bill Clinton's administration (1993-2001) Uzbekistan was never treated as a priority. It suffices to say that in a report by the Deputy Secretary of State Strobe Talbott from 1997 concerning the policy towards this region Uzbekistan was not mentioned even once ${ }^{24}$.

Cooperation between Washington and Tashkent had not been to extensive until the attacks from 11 September 2001, which were used by president George W. Bush and his political environment dominated by neo-conservationists to commence a campaign to spread the world geopolitical influences under the banner of "war against terrorism". The Anti-Muslim campaign of Washington corresponded to the rhetoric and policy of Islam Karimov, who perceived radical political Islamism as the main threat to his power and stability of the political system. The common perception of the enemy and common interests lay at the basis of the American-Uzbek rapprochement. In December 2001 the American secretary of state Colin Powell visited Tashkent ${ }^{25}$.

Cooperation of both countries in the name of "war with terrorism" was realized above all in a broadly understood spheres of defence and security. Its most measurable manifestation was signing a bilateral agreement in $2001^{26}$, making it possible for the American aircraft subordinated

23 US Relations with Uzbekistan, https://www.state.gov/u-s-relations-with-uzbekistan (31.10.2020).

24 Cf. Anatomy of a Crisis: US-Uzbekistan Relations, 2001-2005, Uppsala 2006, p. 5.

25 Joint Press Conference with President Islam Karimov, https://2001-2009.state.gov/secretary/ former/powell/remarks/2001/dec/6749.htm (31.10.2020).

26 U.S.-Uzbekistan 2001 Status of Forces Agreement. 
to the U.S. Central Command (CENTCOM) responsible for the regions of the Near East and Central Asia to have access to the airport and the military base, the Karshi-Khanabad airfield in southern Uzbekistan, frequently called $\mathrm{K} 2$, to transfer soldiers and military equipment during the aggression in Afghanistan in the years 2002-2004. The base, by Americans called with a cryptonym Stronghold Freedom, was used by the $416^{\text {th }}$ Air Expeditionary Wing of the American Air Forces taking part in combat operations against the Talib government for transhipping and refuelling during the flights to the most imprortant American base in the area of Afghanistan - Bagram. American secretary of defence Donald Rumsfeld, who called Uzbekistan a "wonderful” ally during one of his visits in Tashkent, was a particularly enthusiastic advocate of the American-Uzbek military cooperation ${ }^{27}$. Islam Karimov's government perceived cooperation with the United States as an opportunity to gain lucrative contracts, modernize their own military forces and strengthen their strategic position and, at the same time, as a hope for military annihilation of interior opponents - the militants of the Islamic Movement of Uzbekistan and Hizb-ut Tahrir, as well as the external ones - the government of Afghan Talibans and Al-Qaeda organization, perceived as a very serious threat to Uzbekistan's security (radical Islamists aimed to overthrow secular regimes and establish the Central Asiatic Caliphate) ${ }^{28}$. Closer military relations between Washington and Tashkent also aimed at closer political and economic relations. This assumption was realized only in part. The funds from many American programs of financial aid for Uzbekistan found their way to non-governmental organizations, which were largely outside the control of the government in Tashkent. Islam Karimov was particularly suspicious of the fact that organizations which criticized, or insufficiently affirmed his policies also received funds. Despite that, Islam Karimov clearly supported the American aggression in Iraq in 2003, thus condemning the policy pursued by Saddam Hussein.

The American-Uzbek relations began to get worse when the authorities in Tashkent observed with growing anxiety the so-called "colour revolutions" in the post-Soviet area - "the rose revolution" in Georgia in 2003, "the orange revolution" in Ukraine in 2004 and "the tulip revolution" in Kyrgyzstan in 200529. The authorities in Washington did not

27 J. Hendren, Rumsfeld Hints at Bases in Uzbekistan, https://www.latimes.com/archives/la-xpm2004-feb-25-fg-uzbek25-story.html (31.10.2020).

28 Anatomy of a Crisis..., p. 16.

29 Cf. K. Kozłowski, Kolory rewolucji, Warszawa 2012. 
conceal their favour towards anti-government demonstrators, frequently openly supporting them since as a result of protests the authorities reached out for clearly pro-American forces (at least in the first two cases).

A crisis in American-Uzbek relations took place after the tragic events in Andijan in May 2005. Protests broke out in part of Uzbekistan where demonstrators demanded liberation of 23 local entrepreneurs arrested on charges of extremism, fundamentalism and separatism as a result of purges in public administration in Andijan (its victims were mostly supporters of the previous governor of the region). The protests were brutally suppressed by the Uzbek armed forces on 13 May 2005. Islamic organizations - the Muslim Movement of Uzbekistan and Hizb-ut Tahrir were accused of organizing the protests. According to the official data, 187 persons were killed while unofficial estimates give much bigger numbers, even over a thousand ${ }^{30}$. It deserves to be mentioned that representatives of the American administration belittled those events, treating the maintenance of a strategically valuable ally from Uzbekistan as a priority. Already after the massacre the American spokesman Scot McClellan appealed to both sides of the conflict for caution emphasizing that pro-democratic aspirations of the Uzbek society should take a peaceful form ${ }^{31}$. Activities were, however, undertaken by the government of Uzbekistan fearing that Washington concealed its true intentions and supported the anti-government protests with an intention of leading to another "colour revolution", overthrowing the regime and establishing even more pro-American authorities. Islam Karimov decided to start activities in advance and he one-sidedly broke the "strategic alliance" with Washington. The Uzbek authorities demanded that the Americans immediately stop using and leave the Karshi-Khanabad base, which the latter were forced to do. The decision was followed by breaking up numerous commercial and economic connections.

After 2005 the Uzbek-American relations became cooler. Islam Karimov returned his earlier policy of isolationism and gave up his aspirations to gain the status of a privileged ally of Washington in the region. Certain attempts to restore the American-Uzbek relations were undertaken by Barack Obama's administration. Tashkent was twice visited by secretary of state Hillary Clinton (in 2010 and 2011), and in 2015 her successor John Kerry came to Samarkand. Those visits did not, however,

\footnotetext{
30 A. Neistat, The Andijan Massacre Remembered, https://www.amnesty.org/en/latest/ news/2015/07/the-andijan-massacre-remembered (31.01.2021).

31 Cf. US Urges Restraint in Uzbekistan, https://www.rferl.org/a/1058864.html (31.10.2020).
} 
bring any measurable benefits - Uzbekistan was moving away from the American zone of influences.

An attempt to restore good relations with the United States was made by Shavkat Mirziyoyev in May 2018 in the course of talks with president Donald Trump during the visit in Washington. Despite the cordial atmosphere of the meeting, the measurable results disappointed the optimists - only 20 economic agreements were signed of the total value of 4.8 billion dollars, which was little in comparison with a much greater scale of Russian and Chinese investments. It should be added that a considerable part of the Uzbek enterprises cooperate with the Russian enterprises subjected to American sanctions and thus they themselves are also subject to the regime of sanctions. This fact significantly limits the possibilities of economic penetration of Uzbekistan by American entities ${ }^{32}$.

\section{The importance of Uzbekistan for the Russian policy}

The territory of Uzbekistan was under the control of the Russian Empire, and next the Soviet Union for over a hundred years. After Russians and Ukrainians, Uzbeks were the third most numerous nationality of the USSR. The inhabitants of Uzbekistan commonly speak Russian (though in different degrees of fluency) and despite the policy of Uzbekization pursued by Islam Karimov this language plays an enormous role in the Uzbek media, education, science and culture. Many diplomats, journalists and scientists of this Central Asian country are graduates of Russian universities. A very numerous Uzbek diaspora and even a greater group (a few million) of temporary workers from Uzbekistan live in Russia. The Uzbek-Russian cultural and economic connections are very strong and multi-dimensional.

Considering the exceptionally close bonds between the two states following from several decades of common history and economic cooperation, Russia may seem Uzbekistan's most obvious ally. However, till recently the reality was much more complicated. In the 1990's Islam Karimov adopted a nationalistic course and he attempted to create an Uzbek "imagined community" not only by referring to the idealized history of the Timurid Empire but also to the negation of the Russian cultural heritage and

32 S. Hedlund, Uzbekistan emerging from isolation, https://www.gisreportsonline.com/uzbekistanemerging-from-isolation, politics,2801.html (15.10.2020). 
common historical experiences. In the new Uzbek historical policy and propaganda, the Russian Empire and the Soviet Union were presented in an extremely negative light. In independent Uzbekistan anti-communist rhetoric was used, Soviet monuments and symbols were removed and the common experience of fighting against the Nazi invaders during World War II was negated. The policy of Uzbekization was pursued which found its reflection, for example, in removing the Russian language from the public space, media, education and science. Islam Karimov's resentment towards Russia reached its peak in the period of alliance with Washington in the years 2001-2005. Then Uzbekistan - besides Georgia, Ukraine, Azerbaijan and Moldavia - openly entered the composition of the antiRussian alliance GUUAM. The Uzbek-Russian relations got warmer after Tashkent broke up the political and military alliance with Washington following the events in Andijan. However, a breakthrough in mutual relations was still very far ahead ${ }^{33}$.

Bilateral relations between Moscow and Tashkent thawed considerably after Shavkat Mirziyoyev became president. One of the priorities in the new president's foreign policy was clear economic and political rapprochement with the Russian Federation. The breakthrough in relations with Moscow was possible, among other things, because Uzbekistan completely gave up the anti-Russian and anti-communist rhetoric (questioning any positive aspects of the functioning of Uzbekistan as a republic within the Soviet Union), which has been used for over 25 years of Uzbek independence. The statements like that, especially from high politicians and officials, are generally treated by the Russian authorities as unacceptable or even hostile and making close cooperation impossible ${ }^{34}$. The role of a mediator who was the patron in the reconciliation between the two governments was performed by Alisher Usmanov, an exceptionally influential Russian billionaire of Uzbek origin, by family bonds related with president Mirziyoyev. Usmanov became a political ally of the Uzbek president and a patron of the state's transformation in a neoliberal spirit. Their familiarity may be testified to by the fact that Mirziyoyev frequently made foreign trips in the billionaire's plane ${ }^{35}$.

33 Ibidem.

34 Paradoxically, Islam Karimov preserved a number of the Russian social and economic models in Uzbekistan, while fighting against the Russian symbols, ideology and historical remembrance, whereas Shavkat Mirziyoyev introduces the model of neoliberal capitalism in the state but he does not struggle against the symbolic and historical heritage of the USSR.

35 R. Sattarov, Alisher Usmanov: Uzbekistan's Oligarch of Choice, https://carnegie.ru/commentary/74756 (5.11.2020). 
A momentous event in the Russian-Uzbek relations was Vladimir Putin's visit in the Uzbek capital in October 2018. The Russian leader came to Tashkent with an unusually big delegation (estimated at more than a thousand people) composed of experts, diplomats, entrepreneurs, lawyers and engineers. During the summit conference, 785 economic agreements were signed worth of 27 billion dollars. Of central importance was a project of building a 2.4-gigawatt atomic power plant in Uzbekistan (which would satisfy the total energetic demand of the country). The meeting of presidents Vladimir Putin and Shavkat Mirziyoyev resulted in preparing and signing a document entitled Program of Economic Cooperation between the Uzbek and Russian Governments for 2019-2024. The aim of this bilateral agreement was to determine the priority areas of cooperation and activization of cooperation in the field of bilateral undertakings. Since then the document became the grounds for the trade and economic cooperation between Moscow and Tashkent. The subject of talks during a later visit of the minister of foreign affairs Sergey Lavrov in Tashkent in January 2020 was the possibility of Uzbekistan membership in the Eurasian Economic Union. Uzbekistan and Russia also resumed military cooperation. Tashkent returned to active participation in common undertakings of the Shanghai Cooperation Organisation. In 2017 and 2019 common maneuvers of the armed forces of Russia and Uzbekistan took place. Uzbekistan also purchased Russia SU-30 airplanes and Mi-35M helicopters ${ }^{36}$. The hot subject in the Uzbek public debate now is stronger integration with Russia - accession to the Eurasian Economic Union and renewal of membership in the pact of collective defence called the Collective Security Treaty Organization (the country joined and left the treaty twice; Uzbekistan belonged to this organization in the years 1994-1999 and 2005-201237.

The Uzbek-Russian relations are gradually becoming closer and closer; however, the political elites around Shavkat Mirziyoyev are trying to prevent reducing the Central Asian state to the status of a satellite around Moscow. The disproportion of both countries' potentials is remarkable and therefore the authorities in Tashkent are trying to build and strengthen the bonds with the Russian Federation, at the same time balancing it with the development of relations with other countries.

36 S. Hedlund, Uzbekistan emerging from isolation, https://www.gisreportsonline.com/uzbekistanemerging-from-isolation, politics,2801.html (15.10.2020).

37 Cf. F. Tolipov, Uzbekistan Without CSTO, https://www.cacianalyst.org/publications/analyticalarticles/item/12652-uzbekistan-without-the-csto.html (31.01.2021). 


\section{Uzbekistan and the Chinese Project of a New Silk Road}

After the fall of the Soviet Union, the People's Republic of China started to see expansion in central Asia as the main economic and geopolitical priority. Realization of this goal was facilitated by the geographical vicinity between China and five states of post-Soviet Central Asia, spectacular development of the Chinese economy and the critical situation of Central Asian economies which needed credits and direct foreign investments. The economic expansion was gradually followed by the extension of political and economic influences. Due to over a hundred years of the functioning of the whole cultural space of Central Asia within the Russian orbit of influences, the cultural links of the region with China were limited but the authorities of Beijing undertook efforts to build them gradually. At present the People's Republic of China is the largest direct investor in Central Asia and the most important trade partner of the region ${ }^{38}$.

In this aspect the case of Uzbekistan is not fully representative for the regional trends. In the period of Islam Karimov's isolationist foreign policy the Uzbek authorities tried to oppose the Chinese economic expansion. Of all states of Central Asia, the political and economic influences of Beijing have been and still are the weakest. This situation is, however, changing gradually. The relations between China and Uzbekistan are increasingly closer. The state's opening to the foreign capital enabled the People's Republic of China to enter the lucrative Uzbek market. In 2019 the volume of the Uzbek-Chinese turnover was 7.6 billion dollars, which corresponds to $18.1 \%$ of the Uzbek foreign trade. At the beginning of 2020 the Chinese economic entities had shares in 1652 enterprises (which constitutes 16\% of all), above all in the sectors of oil and gas exploitation, textiles, telecommunications, agriculture, chemical industry and the building industry. The Chinese state grants large-scale credits to Uzbek enterprises. The Chinese telecommunications concern closely cooperates with the Uzbek monopolist UzbekTelekom in modernizing the cellular network. Agriculture is an important area of investment (Chinese enterprises invest in the Uzbek irrigation techniques) ${ }^{39}$.

Since 2016 Tashkent and Beijing have been developing cooperation in the fields of foreign trade and common infrastructural projects. Due

\footnotetext{
38 Cf. O. Limanov, Uzbekistan-China Relations During the COVID-19 Pandemic, https://cabar. asia/en/uzbekistan-china-relations-during-the-covid-19-pandemic (5.11.2020).

39 Ibidem.
} 
to its strategic location in the heart of Asia, Uzbekistan is the key link of the infrastructural and trade program initiated by China, One Belt - One Road (OBOR), which in the press is sometimes called the New Silk Road. One of the basic aspects of this multi-dimensional investment program (maybe the largest in the whole history of mankind) is the road and the rail transport corridor leading from China through Kyrgyzstan, Uzbekistan, Turkmenistan and Iran to Turkey. A particularly spectacular example of Chinese investments in China is the rail tunnel Kamchiq in the Qurama mountains which is $19.2 \mathrm{~km}$ long and which connects Tashkent with the Fergana Valley. In May 2017 Shavkat Mirziyoyev paid a visit in Beijing where a program worth of 23 billion dollar of direct investments of the People's Republic of China into various branches of the Uzbek economy was adopted. In October 2018 the prime ministers of both countries Abdulla Aripov and Li Keqiang signed an agreement on partnership in the areas of industry, energy and transport ${ }^{40}$. The People's Republic of China is becoming the source of investments and creditor for the Uzbek state. China also took patronage of the Uzbek governmental project to reduce poverty ${ }^{41}$.

The relations between both countries are first of all of economic character but the People's Republic of China is also engaged in cultural diplomacy in Uzbekistan. Confucius Institutes, which spread the Chinese culture and language, operate in Tashkent and Samarkand. The abolishment of visas for Chinese citizens in January 2020 was supposed to popularize Uzbekistan as an attractive tourist destination; however, this plan failed because of the global COVID-19 pandemic. One of the most important areas of geostrategic cooperation between Beijing and Tashkent is the Shanghai Cooperation Organization ${ }^{42}$.

The People's Republic of China carries out increasingly intensive economic expansion in Uzbekistan by providing credits to enterprises, developing the infrastructure and participating in investments. As yet it is difficult to notice any signals that the growing economic presence of China is translating into political influences (though the political and economic model of Uzbekistan seems to become more and more similar to the Chinese one). Due to the strong cultural and historical links, Rus-

40 S. Hedlund, Uzbekistan emerging from isolation, https://www.gisreportsonline.com/uzbekistanemerging-from-isolation, politics,2801.html (15.10.2020).

41 U. Hashimova, https:/thediplomat.com/2020/10/uzbekistan-teams-up-with-china-on-poverty-reduction/ (5.11.2020).

42 Cf. Gao Fei, The Shanghai Cooperation Organization and China's New Diplomacy, Antwerp 2010, p. 13. 
sia's geostrategic and political influence seems stronger. The situation can, however, gradually change for the benefit of China, which already now possesses the largest power in the region (additionally, showing an increasing tendency) together with a more and more dynamic expansion of the Chinese capital and a slow but systematic development of Beijing's political and cultural influences. Although sometimes symptoms of competition between Russia and China for influences in Uzbekistan and other countries of Central Asia can be noticed, both powers have a number of common goals, the most important of which is not to allow the United States to gain too big influence on the region.

\section{Uzbekistan and Turkey}

The Republic of Turkey, as the first of all countries of the world, recognized Uzbekistan's independence on 16 December 1991 and till today it has occupied a special place in its foreign policy. Both countries are connected by the civilizational, cultural and ethnic closeness as well as language similarity. For many decades Turkey has been trying - with varying intensity - to incorporate the geopolitical strategy of integration of the Turkish language space "From Sarajevo to Yakutsk" under the banner of the ideology of pan-Turkism, which derives as back as from the 1880 's ${ }^{43}$. To give an example, an oppositional organization Birlik referred to pan-Turkism ${ }^{44}$.

Ankara's ambitions to lead the Turkish (Turkic) nations became particularly clear after the disintegration of the Soviet Union. In that period Turkey developed large scale activities and initiatives in the area of soft power addressed to the inhabitants of Azerbaijan and Central Asia such as scholarship programs, youth exchange and learning the Turkish language. Besides, it made its TV and radio programs available to the inhabitants of post-Soviet regions. Islam Karimov was the first leader of a Central Asian country who visited Ankara. At the beginning of the 1990's Turkey granted generous loans to Uzbekistan. It also supported modernization of the Uzbek armed forces with a non-returnable aid. However, the relations got worse when Turkey granted asylum to Muhammad Salih, a counter-candidate of Islam Karimov in presidential elections. In the later period the Uzbek authorities accused Ankara of

43 J. Landau, Pan-Turkism: From Irredentism to Cooperation, Bloomington-Indianapolis 1995.

44 Cf. V. Babak, D. Vaisman, A. Wasserman, Political Organization in Central Asia and Azerbaijan, London-Portland 2004, p. 352. 
attempting to interfere in its interior matters. The relations between both countries were additionally cooled down by Ankara's critical attitude towards the events in Andijan in 2005 (Islam Karimov called off his participation in a multilateral conference of Turkish states and broke up military relations with Turkey). The Uzbek-Turkish reconciliation did not take place until the presidency was assumed by Shavkat Mirziyoyev, who visited Ankara in October 2017 as the first Uzbek leader since the 1990's. In his speech he spoke about his profound longing for the brotherly nation. Those sentimental words were accompanied by signing economic contracts worth 3.5 billion dollars ${ }^{45}$.

Even though it might seem that Recep Tayyip Erdogan has given up, if only partly, the project of pan-Turkism for the vision of the restitution of the Ottoman empire, this does not mean a loss of interest in geopolitical influences in Uzbekistan. The Turkish leader considers himself the spokesman and defender of all Muslims in the world, especially those speaking Turkic (which can be seen on the example of Azerbaijan). Despite certain unfavourable conditions, such as considerable geographical distance between Ankara and Tashkent and a lack of any special traditions of cooperation between the Turks and the Uzbeks, president Erdogan does not give up his dreams about extending his influences onto the area of historical Western Turkestan.

The leaders of Turkey and Uzbekistan keep cordial interpersonal relations. Shavkat Mirziyoyev was hosted in Ankara on 19-20 February, 2020. His meeting with president Recep Erdogan was extremely successful. Even though the scale of direct investment of the Republic of Turkey in Uzbekistan is incomparably smaller than the Chinese or Russian ones, Ankara and Tashkent are systematically making their cooperation increasingly closer both in the spheres of diplomacy, strategy as well as economy and trade ${ }^{46}$.

\section{Final remarks}

Today Uzbekistan remains the state of peripheral capitalism but its importance is growing systematically. A considerable demographic, economic and raw materials potential make this country gradually win

45 G. Dirik, From Hostility to Fraternity: Turkish-Uzbek Relations, https:/www.dailysabah.com/ op-ed/2019/06/21/from-hostility-to-fraternity-turkish-uzbek-relations (3.11.2020).

46 Cf. Relations Between Turkey and Uzbekistan, http://www.mfa.gov.tr/relations-between-turkeyand-uzbekistan\%20.en.mfa (3.11.2020). 
advantage over other centers of the region. After years of international isolation and a conservative social and economic policy (largely maintaining the etatist Soviet model) Uzbekistan carries out transformation of its economy in the spirit of neoliberal capitalism and at the same time opens the state to various forms of international cooperation and foreign investment. As a result, this Central Asian country, which was isolated till not so long ago, is becoming an object of competition between the world powers for economic and geopolitical influences.

So far Uzbekistan has not become a satellite state or a quasi-colony of any of the powers. The multi-vector policy pursued by the political environment of Shavkat Mirziyoyev seems so far to successfully prevent the country being dominated by any outside center. After the events from 2005 the United States lost its remarkable influences and the possibilities to regain them (in the face of Washington getting relatively weaker and the national rivals getting stronger, with interior problems of the USA and a growing involvement in other parts of the globe) do not seem considerable. At present it is Russia, clearly considering the political and economic relations with Tashkent to be extremely significant, which seems to be the power of the broadest influences in this Central Asian republic. Numerous historical and civilizational links, similar cultural codes, common knowledge of the Russian language in Uzbekistan, a big Uzbek diaspora in Russia - all these factors place Moscow in a privileged position. The Uzbek president takes a double-fold attitude in this aspect: on the one hand, he supports closer relations of his country with Russia while on the other, he wants to avoid the status of the Russian protectorate. A significant role in balancing the Russian influences is played by China, which promotes economic expansions in Central Asia on an increasingly greater scale. It could be supposed that Uzbekistan, as an important transit state lying on the New Silk Road, will systematically make its ties with China closer. A gradual increase of the power and geopolitical ambitions of Beijing allow to presume that the Chinese influences in Uzbekistan - like in other states of the region - will systematically grow. It is hard to imagine that in a longer time perspective anybody could challenge the Chinese expansion. In this context it is worth to emphasize the significant role of Turkey, connected with Uzbekistan by means of strong cultural and civilizational bonds and developing close relations with Tashkent. To conclude, a certain role of other Muslim countries (Saudi Arabia, the United Arab Emirates, Qatar) as well as unexpectedly close relations between Uzbekistan and 
South Korea should be mentioned ${ }^{47}$. These countries do not, however, play any dominant role in the Uzbek foreign policy.

It can be supposed that in the nearest perspective Uzbekistan will still follow the path of establishing a political system based on the synthesis (though distinctly more gentle than till recently) of authoritarian political power and an increasingly neoliberal economic system. It can be expected that in the nearest future the state will keep its relative independence by means of balancing the influences of different powers. In a longer perspective, we cannot exclude the possibility that Uzbekistan will enter the orbit of influences of one power, which most probably will be the People's Republic of China.

\section{Bibliography}

Babak V., Vaisman D., Wasserman A., Political Organization in Central Asia and Azerbaijan, London-Portland 2004.

Bazyleva S.P., Elitnaâ bor'ba i stabil'nost' političeskogo režima v Uzbekistane, «Vestnik RUDN» 2017, vol. 19 No. 1.

Bodio T., Daleki-bliski Uzbekistan, [in:] T. Bodio (ed), Uzbekistan. Historia - społeczeństwo - polityka, Warszawa 2001.

Bodio T., Paradoksy polityki posttotalitarnej (na przyktadzie Azji Centralnej), [in:] M. Karwat (ed.), Paradoksy polityki, Warszawa 2007.

Bodio T., Uzbekistan - państwo $w$ totalnej przebudowie, «Nowa Polityka Wschodnia» 2020, No 2.

Dirik G., From Hostility to Fraternity: Turkish-Uzbek Relations, https://www.dailysabah.com/ op-ed/2019/06/21/from-hostility-to-fraternity-turkish-uzbek-relations (24.05.2021).

Džanašiâ V., Uzbekskaâ ottepel', Expert.ru, https://expert.ru/expert/2018/13/uzbekskayaottepel (24.05.2021).

Hedlund S., Uzbekistan emerging from isolation, Geopolitical Intelligence Service, https:// www.gisreportsonline.com/uzbekistan-emerging-from-isolation, politics, 2801.html (24.05.2021).

Hopkirk P., Wielka Gra. Sekretna wojna o Azje Środkowa, Poznań 2011.

Karimow I., Uzbekistan na progu XXI wieku, Warszawa 2001.

Kozłowski K., Kolory rewolucji, Warszawa 2012.

Landau J., Pan-Turkism: From Irredentism to Cooperation, Bloomington-Indianapolis 1995.

Limanov O., Uzbekistan-China Relations During the COVID-19 Pandemic, https://cabar.asia/ en/uzbekistan-china-relations-during-the-covid-19-pandemic (5.11.2020).

Marszewski M., Odwilz w Uzbekistanie. Reformy prezydenta Mirzijojewa, «Komentarze OSW» 16.07.2018, No. 278.

Mirzoân G., Posle Karimova, Expert.ru, http://expert.ru/2016/09/1/poslekarimova (24.05.2021).

47 Cf. A.V. Rinna, Uzbekistan: The Key to South Korea's Central Asia Strategy, https://thediplomat.com/2017/11/uzbekistan-a-key-to-south-koreas-central-asia-strategy (31.01.2021). 
Paderina S., Uzbekskij Den Siaopin: novaâ vnešnââ politika Šavkata Mirzieeva, Russkij sovet po mezdunarodnym delam, https://russiancouncil.ru/blogs/sofia-paderina/33998 (24.05.2021).

Ruziev K., Uzbekistan's Development Experiment: An Assessment of Karimov's Peculiar Economic Legacy, «Europe-Asia Studies» April 2020.

Sattarov R., Alisher Usmanov: Uzbekistan's Oligarch of Choice, Carnegie Moscow Center, 16.11.2017, Downloaded from: https://carnegie.ru/commentary/74756 (24.05.2021).

Starr S.F., Continuity and Change in Uzbekistan, 1991-2016, [in:] S.F. Starr, S.E. Cornell, Uzbekistan's New Face, Lanham-Boulder-New York-London 2018.

Weitz R., Uzbekistan's New Foreign Policy: Change and Continuity Under the New Leadership, [in:] S.F. Starr, S.E. Cornell, Uzbekistan's New Face, Lanham-Boulder-New York-London 2018. 